\title{
The Compatibility Analysis of Human Resources Competencies of Makassar New Port (MNP) and Its Curriculum
}

\author{
Sitti Syamsiah ${ }^{\text {* }}$, Ahmad Fauzi ${ }^{2}$, Abdoellah Djabier ${ }^{3}$, Nurwahidah ${ }^{4}$ iD \\ 1,2,3,4 Polytechnics of Makassar Merchant Marine, Makasar, Indonesia \\ *Corresponding author:pipmks@pipmakassar.com
}

\begin{abstract}
Human resources or HR are needed by companies at various scales, be it a large scale or even a small scale. Makassar New Port as a modern organization that developed kept up with the times, implemented a high competency standard in every level of the work unit. To analyze the compatibility analysis of human resources competencies of Makassar New Port (MNP) towards curriculum. The aim of this research is to map the competencies of Makassar New Port Human Resources related to Diploma IV Port and Shipping Management Department Curriculums. The main informants in this research were the MNP staff who were assigned as many as 7 informants. Data were collected by using in-depth interviews and observation methods the result of the research mentioned that there are 3 variables that should be developed to be qualified as Makassar New Port Human Resources Competence which are; Port Business, Port and Logistics, and Port Management. The research results were a consensus obtained from all respondents regarding the variables that affect port competence. And there are 3 variables that have the potential to be developed, namely port business, ports and logistics, and port management.
\end{abstract}

Keywords: Port and Shipping Management Curriculums

$\begin{array}{lll}\text { History: } & & \text { Publisher: Undiksha Press } \\ \text { Received } & \text { : March 16, 2021 } & \text { Licensed: This work is licensed under } \\ \text { Revised } & \text { : March 20, 2021 } & \text { a Creative Commons Attribution 3.0 License } \\ \text { Accepted } & \text { : April 16, 2021 } & \text { CC () () } \\ \text { Published } & \text { : July 25, 2021 }\end{array}$

\section{INTRODUCTION}

Human resources or HR are needed by companies or institutions at various scales, it is a large scale or even a small scale. This is often underestimated by institutions so that many institutions place incompetent human resources and this is included in the category of HR management errors. It will be assigned by the company to be able to find employees who have the best potential that is needed by the institutions. It begins to define human resources and argues that such resources have 'dual managers': individuals and organizations and the term "human resources" is used both - in a business environment and in reference to people working in Organizations (Batarliene et al., 2017; Bradley, 2019; De Mauro et al., 2018; Tambe et al., 2019). However, there are also many HR parties who make various mistakes, the effect turns out to be detrimental to mistakes. One of the important concerns of the HR function has been to identify the correct tools to evaluate employee performance and it is important to note that human resources can be regarded as one of the vital assets, which has been recognized and contributed to the development and achievement (Awad, 2018; Azzeh \& Nuaimi, 2015; Zainal et al., 2020).

Furthermore, in education field, the effort to improve the quality of education and achieve quality human resources in accordance with national competency standards, it is necessary to implement a system of assessing learning outcomes that are good and planned (Sujarwo; Sukmawati; Yahrif, 2019) and to contextualize those professional competencies (Ma et al., 2018). There are some previous research results such as showed statistically significant differences between education contribution and competencies (Akatay et al., 2015; Bahar \& Köroğlu, 2020; Kunskaja, 2019; Masri \& Jaaron, 2017; Melliana et al., 2018; Seetharaman A, 2018). 
Moreover, Indonesia Port Corporation or PT Pelabuhan Indonesia IV (Persero) seeks to take advantage of opportunities in order to increase in corporate performance (Duakaju, 2017). One of them is the execution of the construction of the Makassar New Port as the main gate to accelerate the development of the Eastern Indonesian Region, especially the Makassar Region Port. New Port as a modern organization that develops and always keeps up with the times, applies strict competency standards at every level of work units and each position. Special in the Maritime School is an educational program that prepares human resources in the field of sea transportation (Palayukan \& Limbong, 2020). PIP Makassar as a vocational education institution at Diploma IV level is certainly expected to be able to play a role in preparing marine transportation human resources, as a formal education institution certainly has a planned and systematic guidance process referring to the curriculum. According to Republic of Indonesia Law No. 20 the Year 2013, the curriculum is a set of planning and organization of aim, content, and learning materials as guidance in a learning activity to achieve a particular educational objective (Susandari et al., 2020). It must prepare for a number of challenges when they decide to implement a competency-based curriculum (Nousiainen et al., 2017). The development of curriculum was due to teaching skills and curriculum development in the past that did not have the impact of improving the quality (Cannon \& Widodo, 1994 as cited in (Nurtanto et al., 2020), while the quality of graduates must answer the competency needs of the workforce. The analyses the way the Curriculum constructs human-environment interaction (Parker, 2017) and life-long learning competency (Passow \& Passow, 2017; Talwar et al., 2019).

The curriculum is a significant element in improving the quality of cadets. Therefore, it is necessary to review educational aspects regarding curriculum implementation, school culture, school management, learning materials, and teaching staff (Haryudin, 2016). There are several different ways of thinking about competence, how competence is conceived will make a big difference to the ways competency standards are used and assessed, professional competency (Nikitenko et al., 2017; Pokrovskaia et al., 2019; Sataloff et al., 2017). Competency-based teaching is all about active learning where teachers help students to learn how to learn rather than just learning content (learn how to learn rather than just cover content). This competency-based curriculum contains competency standards and basic competencies in each subject.

This research is interested to find out the curriculum of the Port and Shipping Management Department in the development of the competency requirements of Makassar New Port human resources. And its urgency in gaining a competency-based curriculum contains competency standards and basic competencies in each subject in Port and Shipping Management of Polytechnics of Makassar Merchant Marine. It has an urgency to be deepened in the existing curriculum. And it turns out that covered everything in the Diploma IV Marine Transportation and Port Management curriculum, it is only recommended that it needs deepening of the material for teachers based on the existing curriculum, updating the latest regulations, and following technological developments in the port sector

\section{MATERIALS AND METHODS}

This research used qualitative research method. This research method is basically a scientific method used to obtain data for specific purposes and uses (Creswell, 2012; Kumar, 2011; Sugiyono, 2017). Delphi method is a means of verification of the results of the analysis that had been carried out by researchers. This research aimed to know the opinions of experts, in this case, the respondents who know the issues and problems as well as the actual conditions in the field. The informant was the Head of the MNP Branch (Informant 1), who was considered capable of providing further information and can also provide 
recommendations on who can be the informants in this study. The informants in this research were the MNP staff who were assigned as many as 7 informants. Subjects in this study were 44 Makassar New Port employees, but only 7 as the research subjects. The location of this research was carried out at the Makassar New Port Office. The research was conducted in the even semester in the 2019/2020 Academic Year, which was from February to October 2020. Data were collected by using in-depth interviews and observation methods. There were three data collection methods used to support the implementation of the research process, namely questionnaires, observation, and literature study. A questionnaire is a data collection technique that is done by giving a set of written statements to the respondent to answer (Sujarwo et al., 2020). The questionnaire is a collection of written questions that are used to obtain information from respondents about themselves or things they know. The purpose of distributing the questionnaire is to find complete information about a problem, without feeling worried if the respondent gives answers that are not following the reality in filling out the list of questions. In addition, the respondent knows certain information requested (Singh, 2006). This study used Delphi analysis. Then this factor analysis was carried out used the Delphi method by distributing questionnaires and conducting semi-structured interviews with respondents who had been selected in the previous stakeholder analysis in 65 variables that affected competence.

\section{RESULTS AND DISCUSSION}

\section{Results}

Makassar New Port is one of the National Strategic Projects (NSP). This project is the work of the nation's children. The construction of the Makassar New Port is being carried out in stages. Phase IA was built from 2015 to 2018. The total investment was Rp. 1.51 Trillion. The Phase IA pier is 320 meters long with an installed capacity of 500,000 TEUs. In Phase IB, 330 meters long pier was also built with an installed capacity of 1 million TEUs. For Phase I C, the pier built has a length of 350 meters, with an installed capacity of 1 million TEUs. Stage ID, the length of the pier is 1,043 meters. Based on the stakeholder assessment using the Likert scale, the input data used namely competency characteristics that have been described in the introduction above, where the research object used the result of literary studies and field observations. Based on the results of the literature synthesis, 65 variables affect competence. This factor analysis was carried out using the Delphi method by distributing questionnaires and conducting semi-structured interviews with respondents who had been selected in the previous stakeholder analysis.

The results of the first stage interview were the exploration of components or definitions that significantly affect port competence based on the respondents' opinions. This was a tabular table compilation of the results of Delphi analysis. For Business related to accounting \& financial management, statistical data analysis, manage client relationships, general business administration, human resource management, quality and customer service management, international business, risk management, including emergency management, impact of globalization \& climate change, strategic planning \& management, economic principles, information system management, industrial relations, healthy safety work, corporate social responsibility, port roles and functions, port marketing information system, dangerous cargo regulations. Then affairs-related to port and logistics are planning and operation for conventional cargo terminals (including dry bulk, liquid \& general cargo handling), warehouse transit and warehouse operations, operation of container ships and yards, dangerous cargo operations, equipment operating procedures, solve technical problems, introduction to equipment maintenance \& repair. management-related including the ability to plan, organize, lead \& control, effective oral \& written communication, ability 
to delegate, train \& motivate staff, know two or more languages, ability to adapt to organizational changes, port and port time productivity management, including KPI measurement, port strategic planning, master planning, and operations planning. From the results of the 65 variables that affect port competence, there are still components that have not reached an agreement, so it is necessary to proceed into the next stage. Those are positive responses from all respondents.

Delphi stage II is carried out on variables that have not reached an agreement and new factors in Delphi stage I. The results of Delphi stage I analysis from the respondents will be confirmed (Delphi stage II) again to the same respondent. From the exploration that has been carried out in Stage I, at least 3 agreed variables have been omitted. Namely, the variables Managing client relationships, Cargo station operations, and purchasing. In addition, several variables have not reached an agreement (consensus) between respondents, so it is necessary to carry out Delphi Stage II analysis (iteration I). The results of the first stage interview and based on the results of the second stage questionnaire (Iteration I), finally a consensus was obtained from all respondents regarding the variables that affect competence so that the overall variables. Based on the results of the analysis using the Delphi table in table 6, it shows that there is still a match between the required competency subgroups with the Marine Transportation Management curriculum and the Diploma IV Port and Shipping Management Program. It only needs deepening of the material for teachers based on the existing curriculum and updating the latest regulations and keeping up with technological developments in the port sector. Most of the respondents got positive responses from all statements.

\section{Discussion}

The research finding concerned with the competence is a basic characteristic possessed by an individual who is causally related in fulfilling the criteria needed to occupy a position, the attempts to compare and to standardize qualifications and competencies witness of the complexity of this task (Pokrovskaia et al., 2019). Competency-based teaching is all about active learning where teachers help students to learn how to learn rather than just learning content (learn how to learn rather than just cover content). It is a significant element in improving the quality of cadets. Therefore, it is necessary to review educational aspects regarding curriculum implementation, school culture, school management, learning materials, and teaching staff. The students have to master Basic Competence because competence is the acquisition of knowledge skills and abilities at a level of expertise sufficient to be able to perform in an appropriate work setting (within or outside academia). But, to attain the best level of learners competency is very difficult and still have many problems for students and teachers to attain a good level in their competence (Haryudin, 2016).

Education in Indonesia is undergoing a curriculum transition that was originally in the Competency-based curriculum and the education unit level curriculum developed into curriculum even the most recent was curriculum revised. The development of curriculum was due to teaching skills and curriculum development in the past that did not have the impact of improving the quality (Cannon \& Widodo, 1994 as cited in (Nurtanto et al., 2020), while the quality of graduates must answer the competency needs of the workforce. The analyses the way the Curriculum constructs human-environment interaction (Parker, 2017) and life-long learning competency. Finally, it includes a program of evaluation of the outcomes" and desired in the future (Talwar et al., 2019). It is a significant element in improving the quality of cadets. Based on the results above, it shows that there is still a connection between the required competency subgroups with the students of the Marine Transportation Management curriculum and the Diploma IV Port and Shipping Management Program. 
Some previous results of research were supported conveyed that university students regarding Human Resource competencies and the contribution of education because their competencies becomes more apparent in the success of HR operations (Onsekiz, 2015). Then this study was relevant with the result of research stated that data of lecturers' personality competence data and students' learning motivation was increasing and used to determine the effect of variables synergistically from independent variables (lecturers' personality competence) on the dependent variable (students' learning motivation). Also, this study was stated that the three maritime schools indicate a high level of the lecturers' personality competence. The students' learning motivation is categorized in the high-level category. Personality competence influences the students' learning motivation in PIP Semarang and it has the influence of personality competence on students' learning motivation (Palayukan \& Limbong, 2020). Then the skills analysis at the organizational level provides key information for workforce planning strategies. The competency audit will allow the organization to determine how to leverage its resources most effectively concerning the strategic mission (Rodriguez et al., 2002). Moreover, the competency approach is an effective measurement tool that helps employees agree on a common language and comprehend what is under-stood by superior performance. So that competency management is a core human resources strategy to help align internal behaviours and skills with the strategic direction of the organization as a whole. As shown in the Turkish case, the cultural settings of the organization should be taken into account in developing the model as well as the way the system is aligned with local norms, attitudes, and behaviours (Özçelik \& Ferman, 2006).

Moreover, the development of human resources for the students needed to be carried out in a planned and sustainable manner. The institution must be able to develop HR development programs carefully and directed so that HR development can be carried out properly. Source development Human resources are needed to increase potential or abilities, knowledge and insight, work skills and expertise, abilities managerial, attitude and personality, as well as other factors contained in humans so that employee performance is good and achieves optimal results. One way that companies can do in human resource development is to know the level of ability and skills of each employee by performing competencies owned by human resources such as skill and their competency. It only needs deepening of the material for teachers based on the existing curriculum and updating the latest regulations and keeping up with technological developments in the port sector especially in the compatibility analysis of human resources competencies of Makassar New Port (MNP) towards curriculum of Diploma IV Port and Shipping Management Department of Polytechnics of Makassar Merchant Marine and to become Human Resource professional, one must be well prepared.

\section{CONCLUSION}

Based on the description of the affect port competence, there are still components that have not reached an agreement, so it is necessary to proceed to the next stage, then there is still a match between the required competency subgroups with the compatibility analysis of human resources competencies of Makassar New Port (MNP) towards curriculum of Diploma IV Port and Shipping Management Department of Polytechnics of Makassar Merchant Marine and to become Human Resource professional, one must be well prepared (Society for Human Resource Management, 2018). The results of questionnaires (Iteration I), finally a consensus is obtained from all respondents regarding the variables that affect port competence, that affects is to need deepening of the material for teachers based on the existing curriculum and updating the latest regulations and keeping up with technological developments in the port sector. There are still components that have not reached an 
agreement, so it is necessary to proceed to the next stage. Based on the analysis results, 3 variables have the potential to be developed, namely port business, ports and logistics, and port management. As a recommendation for Iteration I, the planning and operation variables for conventional cargo terminals (including dry bulk, liquid \& general cargo handling) emerge which need to be deepened in the existence of the curriculum. And it turns out that covered everything in the Diploma IV Marine Transportation and Port Management curriculum. It has the urgency to deepen the material for teachers based on the existing curriculum, updating the latest regulations, and following technological developments in the port sector.

\section{REFERENCES}

Akatay, A., Eroğlu, U., \& Özdemir, S. (2015). Competencies of Hr Professionals: a Study on the Hr Competencies of University Students. Journal of Life Economics, 2(4), 47-60. https://doi.org/10.15637/jlecon.104.

Awad, A. (2018). The Effect of Human Resources Competencies on a Firm Performance: A Marketing Perspective (With Reference to Firms Located in UAE). Asian Business Research, 3(1), 60. https://doi.org/10.20849/abr.v3i1.350.

Azzeh, D. Y. A.-, \& Nuaimi, M. Al. (2015). Competency- Based Human Resources Management and Organizational Performance: Riyadh Bank Case Study (Issue December). Master degree. Amman, Jordan: Middle East University.

Bahar, E., \& Köroğlu, E. Ö. (2020). Human Resources Competencies and the Mediation Role of the Organizational Climate. Business \& Management Studies: An International Journal, 8(4), 993-1014. https://doi.org/10.15295/bmij.v8i4.1612.

Batarliene, N., Čižiuniene, K., Vaičiute, K., Šapalaite, I., \& Jarašuniene, A. (2017). The Impact of Human Resource Management on the Competitiveness of Transport Companies. Procedia Engineering, 187, 110-116. https://doi.org/10.1016/j.proeng.2017.04.356.

Bradley, S. (2019). An Exploratory Study of the Role of the Human Resource Information System Professional. Athens Journal of Technology \& Engineering, 6(1), 63-76. https://doi.org/10.30958/ajte.6-1-4.

Creswell, J. W. (2012). Educational Research:Planning, Conducting, and Evaluating Quantitative and Qualitative Research. University of Nebraska-Lincoln.

De Mauro, A., Greco, M., Grimaldi, M., \& Ritala, P. (2018). Human resources for Big Data professions: A systematic classification of job roles and required skill sets. Information Processing and Management, 54(5), 807-817. https://doi.org/10.1016/j.ipm.2017.05.004.

Duakaju, D. et al. (2017). Formulation Of Makassar Strategy New Port And Port Of Bitung AS International Hub Port. Hasanuddin Journal of Applied Business and Entrepreneurship, 1(4), 80-91. https://doi.org/10.26487/hjabe.v1i4.126.

Haryudin, A. (2016). the Students' English Speaking Competence Based on Ktsp Curriculum. Eltin Journal, Journal Of English Language Teaching In Indonesia, 4(2), 1-12. http://e-journal.stkipsiliwangi.ac.id/index.php/eltin/article/download/375/623.

Kumar, R. (2011). Research Methodology: a step-by-step guide for beginners (3rd editio). SAGE Publications Ltd.

Kunskaja, S. (2019). Expert Evaluation of the Expression of Personal Competencies in Professional Activities. European Journal of Economics and Business Studies, 4(2), 197-205. https://doi.org/10.2478/ejes-2018-0052.

Ma, J., Stahl, L., \& Knotts, E. (2018). Emerging roles of health information professionals for library and information science curriculum development: A scoping review. Journal 
of the Medical Library Association, 106(4), 432-444. https://doi.org/10.5195/jmla.2018.354.

Masri, H. A., \& Jaaron, A. A. M. (2017). Assessing green human resources management practices in Palestinian manufacturing context: An empirical study. Journal of Cleaner Production, 143, 474-489. https://doi.org/10.1016/j.jclepro.2016.12.087.

Melliana, Sinulingga, S., Nasution, H., \& Matondang, N. (2018). Human resource competency relationship and competitive advantages in logistic performance improvement. Journal of Physics: Conference Series, 1116(2). https://doi.org/10.1088/1742-6596/1116/2/022026.

Nikitenko, G. V., Zvyagintseva, O. S., Sergienko, E. G., Babkina, O. N., \& Chernikova, L. I. (2017). Development of human resources of the organization with the help of teambuilding model. Quality - Access to Success, 18(157), 132-136. https://www.proquest.com/openview/005c2b56d884310c63d54378fe5dc6b7/1?pqorigsite $=$ gscholar\&cbl $=1046413$.

Nousiainen, M. T., Caverzagie, K. J., Ferguson, P. C., \& Frank, J. R. (2017). Implementing competency-based medical education: What changes in curricular structure and processes are needed? Medical Teacher, 39(6), 594-598. https://doi.org/10.1080/0142159X.2017.1315077.

Nurtanto, M., Pardjono, P., Widarto, W., \& Ramdani, S. D. (2020). The effect of STEM-EDP in professional learning on automotive engineering competence in vocational high school. Journal for the Education of Gifted Young Scientists, 8(2), 633-649. https://doi.org/10.17478/JEGYS.645047.

Onsekiz, Ç. (2015). Competencies of Hr Professionals: a Study on the Hr Competencies of University Students. Journal of Life Economics, 2(4), 47-60. https://doi.org/10.15637/jlecon.104.

Özçelik, G., \& Ferman, M. (2006). Competency Approach to Human Resources Management: Outcomes and Contributions in a Turkish Cultural Context. Human Resource Development Review, 5(1), 72-91. https://doi.org/10.1177/1534484305284602.

Palayukan, N., \& Limbong, S. (2020). Correlation of Lecturers' Competence and the Learning Motivation of Students. 481(Icest 2019), 254-258. https://doi.org/10.2991/assehr.k.201027.053.

Parker, L. (2017). Religious environmental education? The new school curriculum in Indonesia. Environmental Education Research, 23(9), 1249-1272. https://doi.org/10.1080/13504622.2016.1150425.

Passow, H. J., \& Passow, C. H. (2017). What Competencies Should Undergraduate Engineering Programs Emphasize? A Systematic Review. Journal of Engineering Education, 106(3), 475-526. https://doi.org/10.1002/jee.20171.

Pokrovskaia, N. N., Spivak, V. A., \& Snisarenko, S. O. (2019). Developing Global Qualification-Competencies Ledger on Blockchain Platform. Proceedings of 2018 17th Russian Scientific and Practical Conference on Planning and Teaching Engineering Staff for the Industrial and Economic Complex of the Region, PTES 2018, 209-212. https://doi.org/10.1109/PTES.2018.8604177.

Rodriguez, D., Patel, R., Bright, A., Gregory, D., \& Gowing, M. K. (2002). Developing Competency Models to Promote Integrated Human Resource Practices. Human Resource Management, 41(3), 309-324. https://doi.org/10.1002/hrm.10043.

Sataloff, R. T., Johns, M. M., \& Kost, K. M. (2017). Guide to Implementing CompetencyBased Human Resource Management. 
Seetharaman A, S. A. (2018). Analysis of human resource outsourcing with regards to competitiveness of organizations. Open Access Journal of Science, 2(4), 265-272. https://doi.org/10.15406/oajs.2018.02.00085.

Singh, Y. K. (2006). Fundamental of Research Methodology and Statistics. New Age International.

Sugiyono. (2017). Metodologi Penelitian Pendidikan. Rineka Cipta.

Sujarwo; Sukmawati;Yahrif, M. (2019). Improving Students' English Learning Outcomes through PQ4R (Preview, Question, Read, Reflect, Recite, Review) Learning Model at the Eighth Grade Students of SMP Tunas Bangsa Makassar. Celebes Education Review, 1(2), 48-55. https://doi.org/10.37541/cer.v1i2.228.

Sujarwo, S., Sukmawati, S., Akhiruddin, A., Ridwan, R., \& Suharti Siradjuddin, S. S. (2020). An Analysis of University Students' Perspective On Online Learning in The Midst of Covid-19 Pandemic. Jurnal Pendidikan Dan Pengajaran, 53(2), 125. https://doi.org/10.23887/jpp.v53i2.24964.

Susandari, Warsono, \& Faridi, A. (2020). Evaluation of Exercises Compatibility Be tween Revised Bloom's Taxonomy and 2013 Curriculum Reflected in English Textbook. English Education Journal, 10(2), 252-265.

Talwar, D., Chen, W. J., Yeh, Y. L., Foster, M., Al-Shagrawi, S., \& Chen, L. S. (2019). Characteristics and evaluation outcomes of genomics curricula for health professional students: a systematic literature review. Genetics in Medicine, 21(8), 1675-1682. https://doi.org/10.1038/s41436-018-0386-9.

Tambe, P., Cappelli, P., \& Yakubovich, V. (2019). Artificial intelligence in human resources management: Challenges and A path forward. California Management Review, 61(4), 15-42. https://doi.org/10.1177/0008125619867910.

Zainal, H., Rakib, M., Ashar, A. I., Manda, D., Sose, T., \& Setitit, I. (2020). Strategy of human resources development in improving performance Apparatus in the Bone Regency Regional Inspectorate. Pinisi Business Administration Review, 2(1), 35-44. https://doi.org/10.26858/pbar.v2i1.14012. 